Науковий вісник НлТУ України Scientific Bulletin of UNFU

https://nv.nltu.edu.ua

https://doi.org/10.36930/40310403

Article received $10.08 .2021 \mathrm{p}$.

Article accepted 09.09.2021 p.

UDC 631.535 .2
ISSN 1994-7836 (print)

ISSN 2519-2477 (online)

$@ \bowtie$ Correspondence author

I. Ye. Ivashchenko

ivashchenko_iy@ukr.net

І. Є. Іващенко, С. А. Адаменко, С. А. Масловата, І. Д. Жиляк

Уманський національний університет садівництва, м. Умань, Украйна

\title{
ВПЛИВ МІКРОДОБРИВА ФУЛЬВОГУМІН НА УКОРІНЕННЯ ТРОЯНД СОРТУ MILDRED SCHEEL ЧАЙНО-ГІБРИДНОЇ ГРУПИ
}

\begin{abstract}
Досліджено особливості коренеутворення напівздерев'янілих живців троянд сорту Mildred scheel чайно-гібридної групи. Наведено результати впливу різних концентрацій мікродобрива Фульвогумін та поєднання його з іншими видами стимуляторів коренеутворення. Вважають, що для укорінення стеблових живців велике значення має наявність пластичних речовин, зокрема вуглеводів, з якими пов'язані всі основні процеси життєдіяльності рослин. Вихідним матеріалом для розмноження троянд були відділені від рослин частини, а саме - стеблові напівздерев'янілі живці, які висаджували у теплицю навчальнонауково-виробничого відділення УНУС, облаштовану дрібнодисперсним зволоженням. За отриманими результатами з'ясовано, що інтенсивність процесу коренеутворення стеблових живців троянди сорту Mildred scheel залежить не тільки від досліджуваних регуляторів росту, а й від їх концентрації та правильно підібраної комбінації. Застосування всіх препаратів позитивно впливало на індукційні процеси утворення нових тканин живців троянд. Однак, якщо аналізувати тільки частку укорінених живців, то найвищою вона є у варіанті 7 (100\%), при цьому інтегрований показник укорінення становить $61,6 \%$ i не є найвищим 3-поміж досліджуваних варіантів. Тому оптимальнішим ми вважаємо варіант 3 - частка укорінення $90 \%$ й інтегрований показник 69,0. Якщо ж взяти для порівняння Контроль (варіант 8), то тут спостерігаємо 60,0 \% укорінених живців та 22,0\% інтегрованого показника. Варто зазначити також, що використовуючи Фульвогумін у концентрації 100 мл/л отримано 40 \% укорінених живців з інтегрованим показником укорінення $12,0 \%$. Проте, в разі використання такої концентрації Фульвогуміну у поєднанні з Янтарною кислотою (варіант 5) частка укорінення становить 85,0 \% за інтегрального показника укорінюваності 53,8 \%. А поєднання Фульвогуміну 100 мл/л з Нафтилоцтовою кислотою дало значно гірші показники, порівняно із контролем - 40,9% та 10,6 \% відповідно. Очевидно, ці два стимулятори не $є$ повністю сумісними.

Ключові слова: розмноження; живці; калюс; стимулятори коренеутворення; укорінення.
\end{abstract}

\section{Вступ / Introduction}

Велику цікавість для фахівців садово-паркового господарства представляють різноманітні групи троянд, які мають привабливий вигляд і користуються значним попитом. Тому актуальним $\epsilon$ вдосконалення їх вегетативного розмноження для отримання якісного і дешевого садивного матеріалу $[7,9]$.

На сучасному етапі збереження біорізноманіття та раціонального використання рослинних ресурсів важливим завданням $\epsilon$ ï вирощування на основах екологічного орієнтування $[11,13]$. Саме тому під час вирощування садивного матеріалу доцільним $\epsilon$ використання добрив природного походження окремо або $є$ у поєднанні з класичними стимуляторами росту.

Одним із перспективних добрив вважають Фульвогумін, який базується на основі солей фульвових і гумінових кислот, макро- і мікроелементів у хелатній формі та біологічно-активні речовини. Гумінові добрива впливають на рослини впродовж всього періоду їх вегетації. У рослину разом з ними потрапляє багато поживних речовин, таких як: азот, фосфор, калій, кальцій, сірка та інші мікроелементи, а також амінокислоти, вітаміни та ростові речовини. Гумінові речовини стимулюють активацію ферментативної активності всіх клітин рослини. Унаслідок зростає енергетика клітини, змінюються фізико-хімічні властивості протоплазми, покращується інтенсивність обміну речовин. Мембрани клітин кореня стають більш проникливими, внаслідок чого елементи мінерального живлення активно потрапляють із грунту до рослин у вигляді гуміново-мінеральних сполук та посилюється поглинання рослиною поживних речовин. Дихання рослин інтенсифікується завдяки надходженню води та поглинанню кисню рослинами. Унаслідок посилення дихання пришвидшується поділ клітин, ріст кореневої системи та надземної маси, синтез білків, фо-

\section{Інформація про авторів:}

Іващенко Ірина Євгеніївна, канд. с.-г. наук, доцент, кафедра лісового господарства. Email: ivashchenko_iy@ukr.net; https://orcid.org/0000-0001-5831-8490

Адаменко Світлана Анатоліївна, канд. біол. наук, викладач, кафедра лісового господарства. Email: svitlanka0613@ukr.net; https://orcid.org/0000-0003-4656-1180

Масловата Світлана Андріївна, канд. с.-г. наук, ст. викладач, кафедра лісового господарства. Email: svetlanamaslovatay@gmail.com; https://orcid.org/0000-0002-5725-0604

Жиляк Іван Дмитрович, канд. хім. наук, доцент, кафедра біологіï. Email: zhilyak@i.ua; https://orcid.org/0000-0001-6885-836X

Цитування за ДСтУ: Іващенко І. Є., Адаменко С. А., Масловата С. А., Жиляк І. Д. Вплив мікродобрива фульвогумін на укорінення троянд сорту Mildred scheel чайно-гібридної групи. Науковий вісник НлтУ України. 2021, т. 31, № 4. С. $22-26$.

Citation APA: Ivashchenko, I. Ye., Adamenko, S. A., Maslovata, S. A., \& Zhilyak, I. D. (2021). Influence of fulvoumumin microfertilizer on rooting on rooting Mildred scheel rose of tea-hybrid group. Scientific Bulletin of UNFU, 31(4), 22-26.

https://doi.org/10.36930/40310403 
тосинтез, збільшується вихід сухої речовини, що приводить до поліпшення загальної життєдіяльності рослин [2]. Вважають, що чайно-гібридні троянди мають сильніший аромат та частіше використовуються для створення композицій, ніж Флорібунда [4]. Тому для наших досліджень використовували саме їх.

Об'єкт дослідження - напівздерев'янілі живці троянд сорту Mildred scheel чайно-гібридної групи.

Предмет дослідження - особливості коренеутворення живців троянд сорту Mildred scheel за використання мікродобрива Фульвогумін у різних концентраціях та у комбінації з іншими видами укорінювачів.

Мета роботи - удосконалення технології розмноження чайно-гібридних троянд (на прикладі сорту Mildred scheel) шляхом вивчення особливостей мікродобрива Фульвогумін у різних концентраціях та у поєднанні з іншими видами стимуляторів коренеутворення.

Для досягнення зазначеної мети визначено такі основні завдання дослідження: проаналізувати наукову літературу, що відповідає тематиці дослідження; визначити оптимальну концентрацію та комбінацію регуляторів росту, необхідну для укорінення; дослідити основні біометричні показники для аналізу ефективності впливу стимуляторів росту на подальший розвиток рослин; проаналізувати результати й оцінити ефективність кожного методу стимуляції.

Наукова новизна отриманих результатів дослідження - вперше здійснено наукові дослідження щодо різних концентрацій мікродобрива Фульвогумін та його комбінацій з іншими регуляторами росту для стимулювання коренеутворення напівздерев'янілих стеблових живців троянд.

Практична значущість результатів дослідження визначено оптимальну концентрацію мікродобрива Фульвогумін, яка сприяє активному росту коренів у стеблових живців троянд під час їх вегетативного розмноження.

Аналіз останніх досліджень та публікацій. Сортові троянди розмножуються тільки вегетативним способом, оскільки в разі насіннєвого розмноження у них відбувається розщеплення усіх сортових ознак. Насіннєве розмноження використовують для вирощування підщеп і в селекційній роботі. Тому зазвичай застосовують окулірування або розмноження живцями $[8,10]$.

Здатність троянд до вегетативного розмноження зумовлена тим, що вони належать до кущів, у яких живі тканини здатні регенерувати цілу рослину з окремих вегетативних органів - стебел, коренів, листків або їх частин $[8,10,11,12]$. При цьому на живцях після їх зрізування активується низка процесів, таких як експресія генів, метаболічні та анатомічні зміни, що пов'язані 3 утворенням рани. З'ясовано, що внутрішня структура стебла живців відіграє важливу роль у процесах укорінення [11].

Процес укорінення залежить також від температури навколишнього повітря, вологості та субстрату [3, 15]. Вивчивши і використавши ці внутрішні і зовнішні чинники, можна впливати на процес коренеутворення для скорочення термінів укорінення живців троянд і вирощування 3 них стандартних саджанців.

Відомо, що для укорінення стеблових живців велике значення має наявність пластичних речовин, зокрема вуглеводів, 3 якими пов'язані всі основні процеси життєдіяльності рослин $[1,7,8,11]$. Проведені дослі- дження 3 використанням сахарози та абсцизової кислоти показали, що використання абсцизової кислоти знижує рівень вуглеводів, призводячи до швидкого в'янення та старіння рослини [1].

Деякі автори досить детально розписують використання янтарної та нафтилоцтової кислоти, для укорінення напівздеревянілих живців різних видів [5, 6, 14]. Щодо Фульвогуміну, то раніше його використовували під час дослідження впливу на посівну якість насіння та біохімічні показники проростків [16]. Тому у своїй роботі застосували наведені вище стимулятори.

Матеріали та методи дослідження. Щоб отримати об'єктивні результати під час дослідження здатності стеблових живців до укорінення, в кожному варіанті дослідів рахували інтегрований показник укорінення за формулою

$$
U=0,33 \cdot P \cdot N_{\text {cep. }},
$$

де: $U$ - інтегрований показник укорінення живців (від 0 до 100); $P$ - кількість укорінених живців у варіанті, \%; $N_{c e p}$ - середній показник укорінення за варіантом, бал; 0,33 - розрахунковий коефіцієнт.

Кількість укорінених живців рахували за формулою

$$
P=\frac{100}{N} \sum_{j=1}^{N} n_{j}, \%,
$$

де: $n_{1}, n_{2}, \ldots, n_{N}-$ кількість укорінених живців у варіанті зі ступенем відповідно 1, 2, та 3 бали, шт.; $N$ - загальна кількість живців у варіанті, шт.

Середній показник укорінення за варіантами рахували за формулою

$$
N_{\text {cep. }}=\frac{1}{N} \sum_{j=0}^{N} n_{j} .
$$

Цей метод дає змогу отримати інтегрований показник укорінення від 0 до 100 балів (або \%). За результатами досліджень оцінювали ризогенну здатність стеблових живців за 6-бальною шкалою, згідно з якою: 0 балів - не укорінилися (0 \%); 1 бал - укорінилися дуже слабко (1-20\%); 2 бали -укорінилися слабо (21-40\%); 3 бали - укорінилися задовільно (41-60\%); 4 бали укорінилися добре (61-80 \%); 5 балів - укорінилися дуже добре (81-100\%).

Початок виконання робіт - I декада липня. Вихідним матеріалом для розмноження троянд були відділені від рослин частини, а саме - стеблові напівздерев'янілі живці. Для досліджень використано сорт троянд чайногібридної групи Mildred scheel.

Живці брали із пагонів поточного року діаметром 5-6 мм, які закінчують або закінчили свій приріст і не встигнули здерев'яніти у період коли у маточних кущів повністю сформувалися бутони. Їх заготовляли з молодих рослин віком 2-3 роки. Заготівлю живців здійснювали вранці. Для визначення зрілості живця перевіряли чи на стеблі обламуються шипи. Нарізали живці завдовжки 5-9 см із двома міжвузлями. Нижній зріз робили косим (кут $\left.-45^{\circ}\right)$ під самою брунькою, а верхній - прямий, на 5 мм вище бруньки. Нижні листки видалили для зменшення випаровування вологи.

На кожен варіант досліду використовували по 20 штук стеблових живців, які замочували в розчинах відповідної концентрації стимуляторів росту. Для досліджень застосовували такі стимулятори коренеутворення у вигляді водних розчинів: ФГ 100 мл/л, ФГ 50 мл/л, ФГ 10 мл/л, НОК $(0,03$ г/л) + ФГ 100 мл/л, Янт. к-та 
$(0,13$ г/л) + ФГ 100, НОК (0,03 г/л), Янт. к-та (0,13 г/л). Контролем слугували живці, оброблені дистильованою водою. Тривалість експозиції у всіх досліджуваних варіантах становила 8 год.

Підготовлені живці висаджували у теплицю навчально-науково-виробничого відділення УНУС, облаштовану дрібнодисперсним зволоженням. Субстратом у теплиці слугувала торфово-піщана суміш (1:1). Грунт у теплиці обробили слабким розчином марганцівки для знищення патогенної мікрофлори. Живці висаджували на 1,5-2,0 см під нахилом $45^{\circ}$. Відстань у рядках становила 5-6 см, між рядками $-8-10 \mathrm{~cm}$.

Підтримання вологості повітря в теплиці на рівні 85$95 \%$ відбувалось за допомогою туманоутворювальної установки. Температура повітря становила $25-30{ }^{\circ} \mathrm{C}$.

\section{Результати дослідження та їх обговорення / Research results and their discussion}

Проведено дослідження щодо впливу стимуляторів коренеутворення на укорінення напівздерев'янілих живців чайно-гібридної групи троянд (на прикладі сорту Mildred scheel) відповідно до вказаних методів і методик. Для досліджень підібрано варіанти з використанням розчинів Фульвогуміну різних концентрацій та в поєднанні з Нафтилоцтовою та Янтарною кислотами. Збирання та оброблення матеріалів проводили на 30 -й день після закладання досліду (дата початку дослідження - 07.07.2020 p., дата проведення обліку 06.08.2020 р.) (рис. 1).

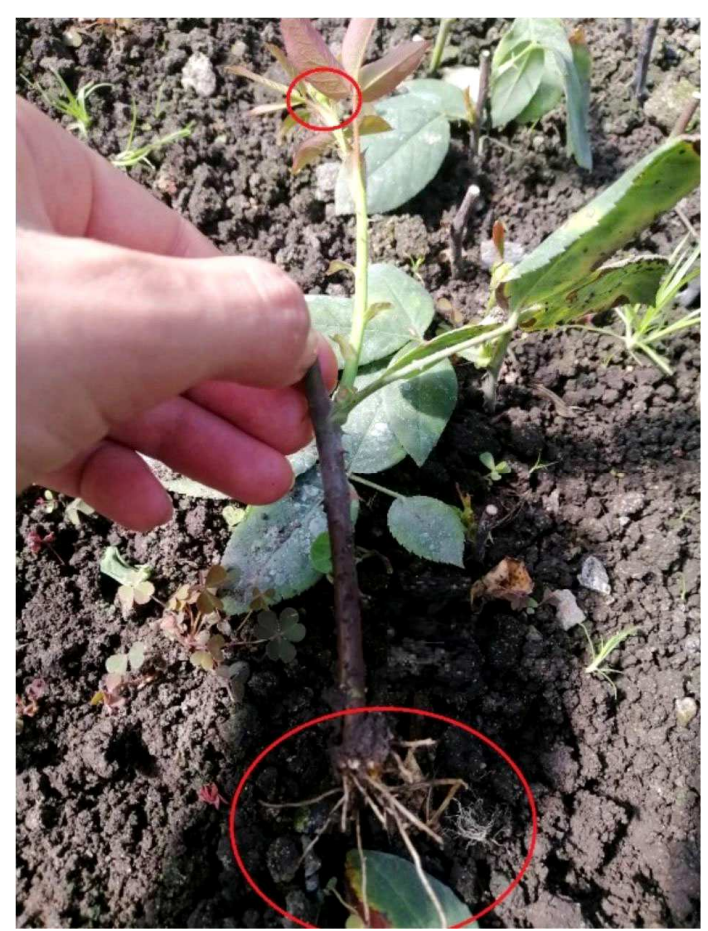

Рис. 1. Укорінений живець троянди сорту Mildred scheel / Rooted cutting of rose varieties Mildred scheel

Дослідженнями встановлено, що частка і якість укорінення стеблових живців троянди сорту Mildred scheel дуже відрізняється залежно від використаних ростових речовин (табл. 1).

Табл. 1. Інтегрований показник укорінення напівздерев'янілих стеблових живців сорту троянди Mildred scheel залежно від використання різних комбінацій стимуляторів росту / Integrated indicator of rooting of semi-woody cuttings of rose varieties Mildred scheel depending on different combinations of growth stimulators

\begin{tabular}{|c|c|c|c|c|c|c|c|c|c|c|c|c|c|}
\hline $\begin{array}{l}\text { № ва- } \\
\text { ріанта }\end{array}$ & $\begin{array}{c}\text { Стимулятор корене- } \\
\text { утворення }\end{array}$ & Концентрація & $\begin{array}{c}\text { Одиниця } \\
\text { виміру }\end{array}$ & $\begin{array}{l}N, \\
\text { шт. }\end{array}$ & \begin{tabular}{|c|} 
Кількість \\
укорінених \\
живців, \\
шт.
\end{tabular} & $\begin{array}{l}n_{0}=0, \\
\text { шт. }\end{array}$ & $\begin{array}{l}n_{1}=1, \\
\text { шт. }\end{array}$ & $\begin{array}{l}n_{2}=2, \\
\text { шт. }\end{array}$ & $\begin{array}{c}n_{3}=3, \\
\text { шт. }\end{array}$ & $P, \%$ & $N_{\text {cep. }}$ & $P \times N_{c e p}$ & $U, \%$ \\
\hline 1 & Фульвогумін & 100 & мл/л & 20 & 8 & 12 & 3 & 5 & - & 40,0 & 0,6 & 24,0 & 12,0 \\
\hline 2 & Фульвогумін & 50 & Мл/л & 20 & 14 & 6 & 1 & 5 & 8 & 70,0 & 1,7 & 119,0 & 39,6 \\
\hline 3 & Фульвогумін & 10 & мл/л & 20 & 18 & 2 & 2 & 4 & 12 & 90,0 & 2,3 & 207,0 & 69,0 \\
\hline 4 & $\begin{array}{c}\text { Нафтилоцтова к-та } \\
\text { Фульвогумін }\end{array}$ & $\begin{array}{l}0,03 \\
100\end{array}$ & $\begin{array}{c}\text { Г/л } \\
\text { мл/л }\end{array}$ & 20 & 8 & 12 & 1 & 6 & 1 & 40,0 & 0,8 & 32,0 & 10,6 \\
\hline 5 & $\begin{array}{l}\text { Янтарна к-та } \\
\text { Фульвогумін }\end{array}$ & $\begin{array}{l}0,13 \\
100\end{array}$ & $\begin{array}{c}\text { Г/л } \\
\text { мл/л }\end{array}$ & 20 & 17 & 3 & - & 12 & 5 & 85,0 & 1,9 & 161,5 & 53,8 \\
\hline 6 & Нафтилоцтова к-та & 0,03 & $\Gamma / \pi$ & 20 & 9 & 11 & 2 & 7 & - & 45,0 & 0,8 & 36,0 & 12,0 \\
\hline 7 & Янтарна к-та & 0,13 & Г/Л & 20 & 20 & - & 4 & 15 & 1 & 100,0 & 1,8 & 185,0 & 61,6 \\
\hline 8 & \multicolumn{3}{|c|}{ Контроль (дистильована вода) } & 20 & 12 & 8 & 2 & 10 & - & 60,0 & 1,1 & 66,0 & 22,0 \\
\hline
\end{tabular}

Згідно з їі даними, найвища частка укорінених живців був у варіанті 7 (Янтарна кислота 0,13 г/л) - $100 \%$. При цьому у контролі (варіант 8) він становив 60,0\%. Висока частка укорінених живців також був у варіантах 3 (Фульвогумін 10 мл/л) та 5 (Янтарна кислота 0,13 г/л та Фульвогумін 100 мл/л) - відповідно 90,0 та 85,0 \%, що значно вище, ніж у контролі. Дещо нижчим був частка укорінення у варіанті 2 (Фульвогумін 50 мл/л) 70,0 \%. Варіанти 1, 4 та 6, де використовували Фульвогумін у високій концентрації та Нафтилоцтову кислоту, мали частка укорінення нижчим, ніж контроль - відповідно 40,0 та 45,0\%.

Щодо інтегрованого показника укорінення живців, то найвищим він був у варіанті 3 (Фульвогумін 10 мл/л) - 69,0\%. Тоді як у контролі (варіант 8) він становив $22,0 \%$. Також високий показник укорінення спостерігався у варіанті 7 (Янтарна кислота 0,13 г/л) - 61, $6 \%$. Дещо нижчим був частка у варіанті 5 (Янтарна кислота
0,13 г/л та Фульвогумін 100 мл/л) - 53,8 \%. У варіанті 2 (Фульвогумін 50 мл/л) інтегрований показник укорінення становив 39,6 \%, що значно менше, ніж у наведених вище варіантах, однак вище порівняно із контролем. Варіанти 1, 4 та 6, де використовували Фульвогумін у високій концентрації та Нафтилоцтову кислоту, показали найнижчі показники укорінення, відповідно - 12, 10,6 та 12,0 \%, що значно менше, ніж у контролі.

Для аналізу ефективності впливу стимуляторів росту на подальший розвиток рослин, було досліджено основні біометричні показники укорінених напівздерев'янілих стеблових живців (табл. 2). Матеріали збирали через три місяці після закладання досліду. Згідно з іiі даними, найбільша довжина коренів була у варіантах 2 (Фульвогумін 50 мл/л) та 5 (Янтарна кислота 0,13 г/л та Фульвогумін 100 мл/л), відповідно - 0,25 та 0,26 м.

$\mathrm{У}$ контролі цей показник становив тільки 0,06 м. Рослини з варіантів 3 (Фульвогумін 10 мл/л) та 7 (Янтарна кислота 0,13 г/л) мали дещо нижчу довжину коре- 
нів - відповідно 0,19 та 0,12 м. У варіантах 1 а 4 довжина утвореного коріння була близькою до показників контролю - 0,08. У варіанті, де використовували нафтилоцтову кислоту (варіант 6), корені не утворились взагалі.

Табл. 2. Біометричні показники укорінених напівздерев'янілих стеблових живців троянди сорту Mildred scheel залежно від використання стимуляторів росту / Biometric indicators of rooted semi-woody cuttings of rose varieties Mildred scheel depending on different growth stimulators

\begin{tabular}{|c|c|c|c|c|c|}
\hline $\begin{array}{c}\text { № } \\
\text { п/п }\end{array}$ & $\begin{array}{c}\text { Варіант } \\
\text { досліджень }\end{array}$ & $\begin{array}{c}\text { Укорі- } \\
\text { нен- } \\
\text { ня, \% }\end{array}$ & $\begin{array}{c}\text { Довжина } \\
\text { коренів, м }\end{array}$ & $\begin{array}{c}\text { Довжина } \\
\text { пагонів, м м }\end{array}$ & $\begin{array}{c}\text { Квіту- } \\
\text { вання }\end{array}$ \\
\hline 1 & ФГ (100 мл/л) & 45 & $0,08^{ \pm 0,04}$ & $0,12^{ \pm 0,02}$ & - \\
\hline 2 & ФГ (50 мл/л) & 70 & $0,25^{ \pm 0,03}$ & $0,50^{ \pm 0,10}$ & + \\
\hline 3 & ФГ (10 мл/л) & 90 & $0,19^{ \pm 0,06}$ & $0,55^{ \pm 0,08}$ & + \\
\hline 4 & $\begin{array}{c}\text { НОК (0,03 г/л) } \\
\text { ФГ (100 мл/л) }\end{array}$ & 40 & $0,08^{ \pm 0,01}$ & $0,27^{ \pm 0,06}$ & - \\
\hline 5 & $\begin{array}{c}\text { Янт. к-та (0,13 г/л) } \\
\text { ФГ (100 мл/л) }\end{array}$ & 85 & $0,26^{ \pm 0,06}$ & $0,49^{ \pm 0,09}$ & + \\
\hline 6 & НОК (0,03 г/л) & 45 & 0 (калюс) & $0,28^{ \pm 0,04}$ & - \\
\hline 7 & Янт. к-та (0,13 г/л) & 100 & $0,12^{ \pm 0,02}$ & $0,35^{ \pm 0,03}$ & - \\
\hline 8 & $\begin{array}{c}\text { КОНТРОЛЬ (дис- } \\
\text { тильована вода) }\end{array}$ & 60 & $0,06^{ \pm 0,04}$ & $0,39^{ \pm 0,12}$ & - \\
\hline
\end{tabular}

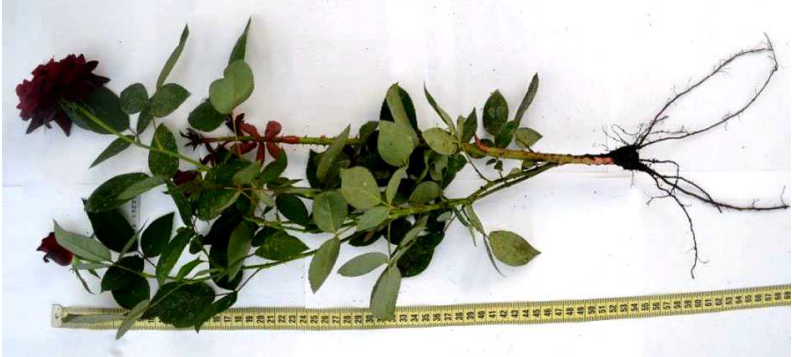

Рис. 2. Укорінена троянда сорту Mildred scheel, вирощена зі стеблового живця, замоченого у розчині Фульвогуміну у концентрації 10 мл/л (через три місяці після закладання досліду) / Rooted rose varieties Mildred scheel grown from stem cuttings soaked in a solution of fulvoumin in concentration $10 \mathrm{ml} / 1$ ( 3 months after the start of the experiment)

Якщо ж характеризувати довжину пагонів, то тут результати були дещо іншими. Найвищу довжину пагонів зафіксовано у варіантах 2 (Фульвогумін 50 мл/л), 3 Фульвогумін 10 мл/л) та 5 (Янтарна кислота 0,13 г/л та Фульвогумін 100 мл/л) - 0,50 м, 0,55 м та 0,49 м. У контролі (варіант 8) цей показник становив 0,39 м. Досить близьким до контролю був варіант 7 (Янтарна кислота 0,13 г/л), де довжина пагонів становила 0,35 м. Варіанти 4 та 6 мали довжину пагонів відповідно 0,27 м та 0,28 м. Найнижчу довжину пагонів мали рослини, де у ролі стимулятора використовували Фульвогумін 100 мл/л (варіант 1) - 0,12 м.

Використання отриманих результатів дасть змогу не тільки збільшити ефективність вегетативного розмноження дослідних рослин, а й істотно підвищити їх якість завдяки формуванню у них потужнішої і краще розгалуженої кореневої системи.

Обговорення результатів дослідження. За отриманими результатами з'ясовано, що інтенсивність процесу коренеутворення стеблових живців троянди сорту Mildred scheel залежить не тільки від досліджуваних регуляторів росту, а й від їх концентрації та правильно підібраної комбінації. Застосування всіх препаратів пози- тивно впливало на індукційні процеси утворення нових тканин живців троянд.

Однак, якщо аналізувати тільки частка укорінених живців, то найвищим він $є$ у варіанті 7 (100\%), при цьому інтегрований показник укорінення становить 61,6 \% і не є найвищим 3-поміж досліджуваних варіантів. Тому більш оптимальним вважаємо варіант 3 - частка укорінення 90 \% й інтегрований показник 69,0. Якщо ж взяти для порівняння Контроль (варіант 8), то тут спостерігаємо 60,0 \% укорінених живців та 22,0\% інтегрованого показника. Тобто, можна припустити, що для активізації процесів коренеутворення потрібна невелика концентрація фульвових кислот. Вважають, що фульвова кислота має здатність розділяти мінеральні поживні речовини на частини іонного розміру, що $\epsilon$ найменшою формою мінералів. У такій формі рослини легко та швидко засвоюють елементи живлення.

Варто зазначити також, що в разі використання Фульвогуміну у концентрації 100 мл/л отримано $40 \%$ укорінених живців 3 інтегрованим показником укорінення 12,0 \%. Це можливо пояснити активізацією надто швидкого енергетичного обміну в середині клітини та між різними клітинами. Внаслідок цього ресурси клітини швидко вигорають.

Проте за використання такої концентрації Фульвогуміну у поєднанні 3 Янтарною кислотою (варіант 5) частка укорінення становить 85,0\% за інтегрального показника укорінюваності 53,8 \%. А поєднання Фульвогуміну 100 мл/л 3 Нафтилоцтовою кислотою дало значно гірші показники, порівняно із контролем 40,9 \% та 10,6 \% відповідно. Очевидно, ці два стимулятори не є повністю сумісними.

\section{Висновок / Conclusions}

1. Найвищу частку укорінених живців зафіксовано у варіанті 7 - $100 \%$. Висока частка укорінених живців також була у варіантах 3 та 5 - відповідно 90,0 та 85,0\%, що значно вище, ніж у контролі (60\%).

2. Щодо інтегрованого показника укорінення живців, то найвищим він був у варіанті 3 (Фульвогумін 10 мл/л) $69,0 \%$. Тоді як у контролі (варіант 8) він становив $22,0 \%$. Також високий показник укорінення виявлено у варіанті 7 (Янтарна кислота 0,13 г/л) - 61, 6 \%.

3. Варіанти 1,4 , та 6 , де використовували Фульвогумін у високій концентрації та Нафтилоцтову кислоту, мали найнижча частка укорінення та інтегрований показник.

4. Під час дослідження біометричних показників укорінених напівздерев'янілих стеблових живців з'ясовано, що найбільш розвинені пагони та корені були у варіантах 2 i 3, де використовували Фульвогумін у концентрації 10 та 50 мл/л.

\section{References}

1. Borochov, A., Mayak, S., \& Halevy, A. H. (1976). Combined Effects of Abscisic Acid and Sucrose on Growth and Senescence of Rose Flowers. Physiologia Plantarum, 36(3), 221-224. https://doi.org/10.1111/j.1399-3054.1976.tb04416.x

2. Buts, M. A., Davydenko, A. F., \& Tunda, G. A. (2003). Instruktsiya po tekhnologii vyrashchivaniya roz v zashchishchennom grunte. Kyiv: Kiyevskoye Opytnopokazatelnoye khozyaystvo po dekorativnomu sadovodstvu, 28 p. [In Ukrainian].

3. Cárdenas-Navarro, \& R., López-Pérez, L. (2011). Vegetative propagation of rose: effects of substrate, light and leaf persistence. Scientia Agropecuaria, Vol. 2(4), 203-211.

4. De Vl Eeschouwer O. (2004). Roses made easy - Octopus Publishing Group Ltd. $10 \mathrm{p}$. 
5. Horielov, O. O. (2010). Vykorystannia stymuliatoriv koreneutvorennia pry vehetatyvnomu rozmnozhenni vilkhy. Naukovyi visnyk Uzhhorodskoho universytetu, 27, 125-127. [In Ukrainian].

6. Hou, Pc., Lin, Kh., Huang, Yj., Wu, Cw., \& Chang, Ys. (2020). Evaluation of vegetation indices and plant growth regulator use on the rooting of azalea cuttings. Horticultura Brasileira, 38, 153159. http://doi.org/10.1590/S0102-053620200207

7. Klymenko, Z. K. (2001). Rozy. Moscow: ZAO "Fyton+", 176 p. [In Russian].

8. Koval, I. V. (2005). Osoblyvosti vuhlevodnoho obminu roslyn rodu Rosa L. Visnyk Cherkaskoho universytetu. Seriia Biolohichni nauky, 71, 51-59. [In Ukrainian].

9. Manushkina, T. M. (2009). Osoblyvosti klonalnoho mikrorozmnozhennia troiandy Rosa hybrida L. Visnyk ahrarnoi nauky Prychornomoria, 3, 131-136. [In Ukrainian].

10. Maurer, V. M., \& Kushnir, A. I. (2008). Metodychni rekomendatsii z rozmnozhennia derevnykh dekoratyvnykh roslyn Botanichnoho sadu NUBiP Ukrainy. Kyiv: NUBiP Ukrainy, 55 p.

11. Monder, M. J., Kozakiewicz, P., \& Jankowska, A. (2017). Effect of Anatomical Structure of Shoots in Different Flowering Phase on Rhizogenesis of Once-blooming Roses. Not Bot Horti Agrobo, 45(2), 408-416. https://doi.org/10.15835/nbha45210854

12. Rubtsova, O. L. (2007). Istoriia doslidzhennia rozmnozhennia troiand v Ukraini. Istoriia ukrainskoi nauky na mezhi tysiacholit, 27, 181-190. [In Ukrainian].

13. Rubtsova, O. L. (2009). Rid Rosa L. v Ukraini: henofond, istoriia, napriamy doslidzhen, dosiahnennia ta perspektyvy. Monohrafiia. Kyiv: Feniks, 404 p. [In Ukrainian].

14. Sliusar, S. I., Yakobchuk, O. M., Kolesnichenko, O. V., \& Mamonova, R. Yu. (2019). Metod otsinky vplyvu ekzohennykh biostymuliatoriv na ukorinennia steblovykh zhyvtsiv. Physiologia Plantarum, 11(12), 128-136. https://doi.org/10.123.60/bio2019.01.014

15. Sobko, V. H. (2004). Analiz systemy rodu Rosa L. (Rosaceae) flory Ukrainy. Introduktsiia roslyn, No. 2, 41-46. [In Ukrainian].

16. Syniavskyi, Yu., Huz, M., Baranov, V., Tehlivets, S., \& Karpinets, L. (2016). Vplyv rehuliatoriv rostu na posivnu yakist nasinnia ta biokhimichni pokaznyky prorostkiv Metasequoia glyptostroboides Hu \& Cheng. Visnyk Lvivskoho universytetu. Seriia biolohichna, 74, 201-208. [In Ukrainian].

I. Ye. Ivashchenko, S. A. Adamenko, S. A. Maslovata, I. D. Zhilyak

Uman National University of Horticulture, Uman, Ukraine

\section{INFLUENCE OF FULVOUMUMIN MICROFERTILIZER ON ROOTING OF MILDRED SCHEEL ROSE OF THE TEA-HYBRID GROUP}

When growing planting material, it is advisable to use fertilizers of natural origin separately or in combination with classical growth stimulants. The aim of this work was to improve the technology of propagation of semi-woody cuttings of tea-hybrid roses (on the example of the variety Mildred scheel) by studying the features of the microfertilizer Fulvogumin in different concentrations and in combination with other types of rooting stimulants. Cuttings were taken from shoots of the current year with a diameter of 5-6 $\mathrm{mm}$, which finish or have finished their growth and did not have time to woody when the parent bushes completely formed buds. They were harvested from 2-3 year-old young plants. Prepared cuttings were planted in the greenhouse of the training, research and production department of Uman National University of Horticulture equipped with mist irrigation system. The results of the research showed that variant 3 appeared to be the most optimal as the percentage of rooting was $90 \%$ and the integrated rooting rate was 69.0 $\%$. If we analyze only the percentage of rooted cuttings, it was the highest in variant $7(100 \%)$, while the integrated rooting rate was $61.6 \%$ and it was not the highest among the studied variants. For comparison, Control (variant 8 ) was $60.0 \%$ of rooted cuttings and $22.0 \%$ of the integrated rooting rate. A high percentage of rooted cuttings was also shown by variant $2-70.0 \%$, respectively, while the integrated rooting rate was $39.6 \%$. We should also note that we obtained $40 \%$ of rooted cuttings with an integrated rooting rate of $12.0 \%$ when using Fulvogumin at a concentration of $100 \mathrm{ml} / \mathrm{l}$. This can be explained by the activation of too rapid energy exchange within the cell and between different cells. As a result, cell resources burn out quickly. However, when using this concentration of Fulvogumin in combination with succinic acid (variant 5), the percentage of rooting is $85.0 \%$ with an integrated rooting rate of $53.8 \%$. And the combination of Fulvogumin $100 \mathrm{ml} / 1$ with Naphthylacetic acid gave significantly worse results compared to the control $-40.9 \%$ and $10.6 \%$, respectively.

Keywords: reproduction; cuttings; callus; root stimulators; rooting. 